\title{
The
}

\section{Antiquaries Journal}

Being the Fournal of the Society of Antiquaries of London

VOLUME XXVIII

JANUARY-APRIL I948

NUMBERS I, 2

\section{CONTENTS}

ExCAVATIONS at ATCHANA-ALALAKH, 1939, by Sir Leonard Woolley, F.S.A. I

War and ARchaeology in Britain, by B. H. St. J. O'Neil, V.-P.S.A. . 20

The Development of Fishing in Prehistoric Europe, by J. G. D.

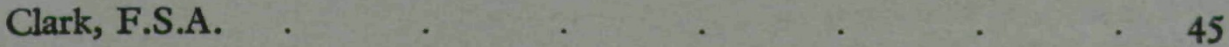

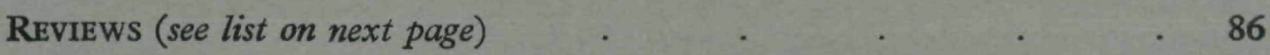

Periodical Literature; Bibliography; Proceedings . $\quad 89$

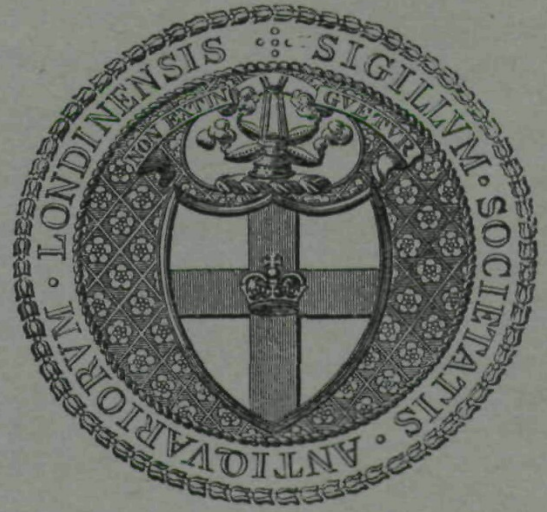

Published by

GEOFFREY CUMBERLEGE. OXFORD UNIVERSITY PRESS

LONDON GLASGOW NEW YORK TORONTO MELBOURNE WELLINGTON

BOMBAY CALCUTTA MADRAS CAPE TOWN 


\section{REVIEWS}

Oudheidkundig Bodemonderzoek in Nederland .

Oldeberg, Metallteknik under Förhistorisk tid .

Richter, Attic Red-Figured Vases: A Survey .

Leeds, A Hoard of Roman folles from Diocletian's reform (A.D. 296) to Constantine Caesar, found at Fyfield, Berks.

FRANCIS EDWARDS LTD.

Booksellers since 1855

We invite inspection of our large stock of books on Archaeology, Art, Anthropology, Exploration, Travel, and Natural History.

We have an unrivalled stock of early and decorative maps of all parts of the British Isles, as well as foreign countries.

YOUR INQUIRIES ARE INVITED

WE BUY BOOKS IN LARGE OR SMALL QUANTITIES

83 MARYLEBONE HIGH STREET LONDON, W.1
Messrs. Myers \& Co. (Booksellers) Ltd.

Esfablished 1889

OLD AND MODERN BOOKS MANUSCRIPTS AND AUTOGRAPH LETTERS purchase for prompt cash COMPLETE LIBRARIES AND

SMALLER COLLECTIONS in Town or Country Catalogues sent on request

Cat. 352. RARE BOOKS

Large Selection of Autograph letters always in stock

80 New Bond Street London, W. 1. (Oxford Street end)

Telephone: MAYFAIR 2931

All communications on Editorial matters and books for review should be addressed to the Assistant Secretary, Society of Antiquaries, Burlington House, London, W. I 


\section{The \\ Antiquaries Journal}

Being the Journal of

The Society of Antiquaries of London

\section{VOLUME XXVIII}

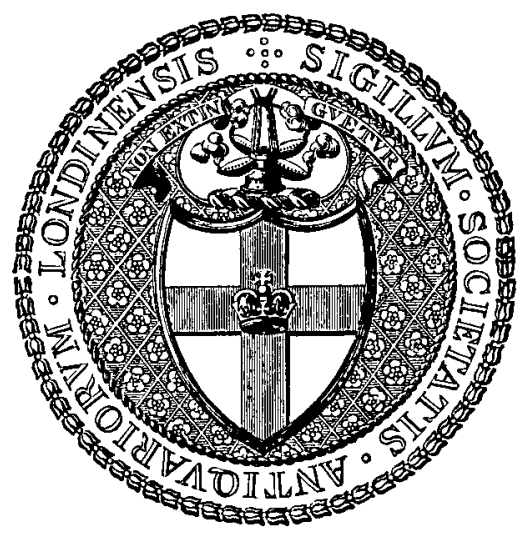

\section{OXFORD UNIVERSITY PRESS}

LONDON GLASGOW NEW YORK TORONTO MELBOURNE

WELLINGTON BOMBAY CALCUTTA MADRAS CAPE TOWN

GEOFFREY CUMBERLEGE

1948 
PRINTED IN GREAT BRITAIN

AT THE UNIVERSITY PRESS, OXFORD

DY CHARLES BATEY, PRINTER TO THE UNIVERSITY 


\section{CONTENTS OF VOLUME XXVIII}

Excavations at Atchana-Alalakh, 1939, by Sir Leonard Woolley, F.S.A. . I

War and Archaeology in Britain, by B. H. St. J. O'Neil, V.-P.S.A. 20

The Development of Fishing in Prehistoric Europe, by J. G. D. Clark,

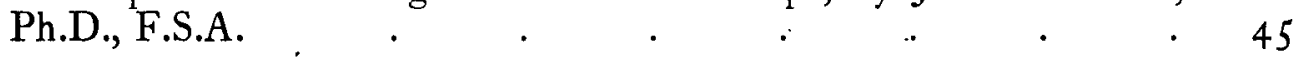

Anniversary Address, by Sir Cyril Fox, D.Litt., Ph.D., F.B.A., President . I I 5

The Incised Ornament on the Celtic Mirror from Colchester, Essex, by Sir Cyril Fox, President, and M. R. Hull, F.S.A. . . . . $\quad$ I 23

Building by King Henry III and Edward, son of Odo. Part I, by J. G. Noppen, F.S.A. $\quad . \quad$. $\quad . \quad . \quad . \quad . \quad . \quad . \quad 138$

A Beaker Interment on Stockbridge Down, Hampshire, and its Cultural Connexions, by J. F. S. Stone, D.Phil., F.S.A. • • • • 149

A Bronze Cauldron from Sompting, Sussex, by E. Cecil Curwen, M.B., F.S.A.

Views of Richmond Palace in the Reign of Charles I, by M. R. Toynbee, Ph.D., F.S.A. . . . . . . . $\quad{ }^{1} 6_{4}$

Notes

Reviews

Periodical Literature

Bibliography

Proceedings of the Society of Antiquaries . . . . . I I 2, 22 I

Index 


\section{LIST OF ILLUSTRATIONS}

Excavations at Atchana-Alalakh, 1939:

Plan of Houses 39/A and 39/B

Plan of Level II, House 39/c.

Plan of the Palace of King Yarim-Lim

a. Yarim-Lim's palace, room 2. b. House site 39/B, level IV

Plate facing 8

$a$. Palace, room 5, looking into room 5A. b. Palace staircase (10)

Plate facing 10

a. Palace, room 12. Painted plaster from the upper story. $b$. Palace, room 12 . In the background, room II

Plate facing

a. Palace, room 17. The staircase and doorway. $b$. Palace, room 17. The stone doorway blocked by boulders

Plate facing

a. Palace, room 17. The four bodies in a box. $b$. Palace, room 17. The pile of burnt bones, stone vessels, and clay vases. c. Palace, room 18 .

$a-h$. Stone cult-figures .

Plate facing

Plate facing

Plate facing

$a$. Red porphyry lamp. b. Stone vases. c. Stone cup and pyxis ..

Plate facing

Seal impressions

War and Archaeology in Britain:

6 Norley Street, Plymouth

Plate facing

Forrens Arch, Canterbury

Five Chimneys, Winchelsea

Plate following

Plate following

44

a. Hall of the Vicars Choral, Exeter. b. Nos. 18 and I9 Watling Street, Canterbury

Plate following

a. Nos. I I to I6 King Street, Portsea. b. St. George's Church, Exeter: the western doorway

Plate following

a. Wrought-iron gate at 32 Smith Square, S.W. I. b. Wrought-iron porch at Sherborne

Plate facing

The Development of Fishing in Prehistoric Europe:

$a$. Leister prong from the Grotte du Mas d'Azil. b. Harpoon-head from the Grotte de Lorthet

Double- and triple-pointed gorges

Forked object and $\mathrm{V}$-shaped gorge

Hypothetical lines of development from gorge to fish-hook

Early fish-hooks from the Near East .

Barbless fish-hooks

Remains of pike with leister prong, from a Mesolithic lake-deposit near Kunda

5

52

Maglemose leister prong from the North Sea

Map showing distribution of the Maglemose summer pike-fishery 59

Barbless bone fish-hooks from Stone Age sites in Denmark and Norway . . $\quad 62$

Hooks of bone and boar's tusk enamel from the Swiss lake-villages $\quad . \quad \ldots \quad$. 64

Hooks from stone cists, Sweden 
Fish-hooks from sub-neolithic sites on Gotland . . . . . . . $\quad 67$

Fish-hooks with external barbs $\quad . \quad$. $\quad . \quad . \quad . \quad . \quad . \quad . \quad .68$

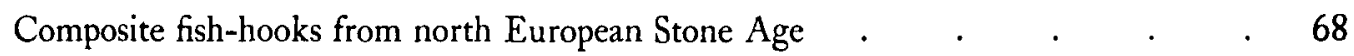

Double hooks of bronze wire from the Late Bronze Age of the Alpine area . $\quad 70$

Single hooks from the Late Bronze Age and Early Iron Age of the Alpine area . 71

$\begin{array}{lll}\text { Map illustrating the prehistoric coastal line-fishery of Scandinavia } \quad . \quad & \text {. } & 77\end{array}$

Hooks from the Norwegian coastal line-fishery . . . . . . $\quad 7_{8}^{8}$

The Incised Ornament on the Celtic Mirror from Colchester, Essex:

The Colchester mirror, showing its probable shape and the incised ornament on the

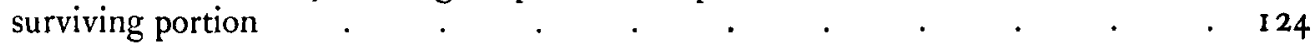

The Colchester mirror: the incised design on the mirror-plate, restored.$\quad$ I 25

'Matting' of various types on the mirror . . . . . . . . . . 127

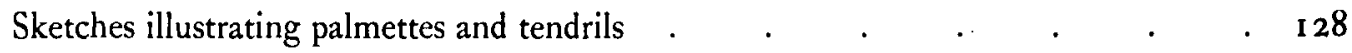

Sketches illustrating sources and examples of Celtic lyre designs with and without palmettes . . . . . . . . . . . . . . $\quad$. 129

The fan, comma, and circle motif of the Colchester mirror . . . . . . . I 30

Mirrors. a. 'Mayer.' b. Birdlip. c. Desborough. d. 'Gibbs' . . Plate facing I 30

The sequential relationship of the four mirror-patterns: Mayer, Colchester, Birdlip, and Desborough . . . . . . .

The bronze cup, and pin, associated with the mirror . . . . . . 136

The pottery associated with the mirror . . . . . . . 137

A Beaker Interment on Stockbridge Down, Hampshire, and its Cultural Connexions:

Sketch-map of Stockbridge Down . . . . . . . . . 149

a. Beaker from Stockbridge Down grave. b. Stockbridge Down grave, showing beaker in situ . . . . . . . . Plate facing

150

A Bronze Cauldron from Sompting, Sussex:

$\begin{array}{lllll}\text { Tentative reconstruction of the Sompting cauldron } & . & . & . & \end{array}$

a. Fragment of the rim of the Sompting cauldron. $b$. Part of the side, showing repairs . . . . . . . . Plate facing

$15^{8}$

Details of the handles of the Sompting cauldron . . . . Plate facing 159

Details of the brim and diagrams showing methods of repairing a cracked plate $\quad 159$

Boss-shaped object of bronze, and outline of axes I I and I 2 superimposed . . $\quad$ I62

Bronze axes from the Sompting hoard . . . . . Plate facing 162

$a$. Bronze axes from the Sompting hoard. $b$. Boss-shaped object of bronze Plate facing 163

Views of Richmond Palace in the Reign of Charles I:

$a$. Drawing by Wenceslaus Hollar in the British Museum Print Room. b. The Moyne-Arcade gallery painting entitled 'Charles I and his family at Nonsuch Palace on the River Fleet' . . . . . . Plate facing

a. Etching by Wenceslaus Hollar, 1638. b. Oil-painting in the possession of the Society of Antiquaries

Plate facing 165 
Romano-British phallic carving, Broadway, Worcs. . . . Plate facing 168 Late British brooches from $a, b$. Glaston, Rutland, and $c, d$. Howletts, Kent

Brooch from Glaston, Rutland

Plate facing $\quad 168$

Brooch from West Stow, Suffolk .

Brooch from Cys-la-Commune, Aisne

Castor beaker from York .

a. d. Miniature jet figures of bears. c. Embossed bronze studs from Malton

a. Phallic amulet from Malton. $b$. Anglo-Saxon brooch from Malton. $c-f$. Objects of jet from Malton and York. $g-h$. Impression of textile fabric from inhumation grave, Malton

Plate facing 175

The Malton brooch

Roman spade-iron from Malton 175

a. Mithraic brooch from Ostia in the Ashmolean Museum, Oxford. b. Bronze Viking drinking-horn mount from Fetter Lane, London

Plate facing 178

Silver pins from $a$, Sawdon, N.R. Yorks., and $b$, Ash, Kent. Bronze bracelets from $c$, Normanton, Wilts., and $d$, Bridlington, Yorks.

Plate facing

Patterns on the bracelets from Bridlington, Knipton, and Normanton

179

Details of the head of a silver pin from Ballinaby, Islay . 180

Tubular bone object from Sawdon, N.R. Yorks.

$18 \mathrm{I}$

Food-vessel and spear-head found at Pentire Glaze, N. Cornwall . . . . . 184

Fragment of early Saxon pot from Northfleet . . . . . . . . $\quad{ }_{1} 87$

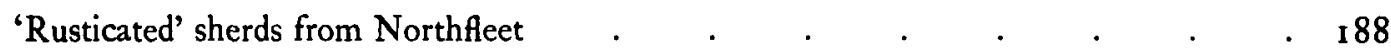

